\title{
Impact of Inflation, Interest Rate, and Industrial Production Index (IPI) on the Amount of Zakat in Central Baznas Period 2011-2017
}

\section{Ramdani Saadillah, Kusnendi, and Firmansyah}

Department of Islamic Economics and Finance, Universitas Pendidikan Indonesia Jl. Dr. Setiabudhi No. 229 Kota Bandung

\section{Abstract}

The purpose of this study was to analyze the impact inflation, interest rates, and industrial production index (IPI) on the amount of zakat at the Central BAZNAS from 2011 to 2017. The method used in this study was explanatory methods with quantitative approaches. The data analysis technique used is the Vector Autoregression (VAR) method, if the data is not stationary at the level and there is cointegration, the method used is Vector Error Correction Model (VECM). The data used in this study are time series data from January 2011 to December 2017 collected from the website of Bank Indonesia, the website of the Badan Pusat Statistik (BPS), and the website of the Central BAZNAS. The results of the VECM test show that in the short term inflation and interest rates each have a negative and not significant effect on the amount of zakat, while the IPI has a positive and insignificant effect on the amount of zakat. Whereas in the long run inflation has a significant negative effect on zakat receipts. Interest rates are negatively significant and IPI has a significant positive effect on the amount of zakat.

Keywords: The Amount of Zakat, Inflation, Interest Rate, Industrial Production Index

(c) Ramdani Saadillah et al. This article is distributed under the terms of the Creative Commons Attribution License, which permits unrestricted use and redistribution provided that the original author and source are credited.

Selection and Peer-review under the responsibility of the ICIEBP Conference Committee.

\section{Introduction}

Indonesia is a country that has the largest Muslim population in the world. With an estimated Muslim population of 205 million. This number represents $88 \%$ of the total Muslim population in the world ((The Pew Forum on Religion and Public Life, 2017)). This fact represents the greatest potential and realization of zakat collection in Indonesia. But in fact, this is contrary to this assumption.

There are several studies that discuss the potential of zakat in Indonesia. First, studies conducted by the Public Interest Research and Advocacy Center (PIRAC) show that the potential of zakat in Indonesia is increasing every year. Based on the survey, PIRAC showed that the average potential of zakat issued by muzakki reached IDR $684,550.00$ in 2007, an increase from the previous average of IDR 416,000.00 in 2004. 
Second, the study conducted by PEBS FEUI used the approach of the number of muzakki from the Indonesian Muslim population by assuming 95 percent of muzakki pay zakat, it can be estimated that the potential of zakat collection in 2009 will reach Rp. 12.7 trillion (Indonesia Economic Outlook, 2010). Third, research conducted by the UIN Syarif Hidayatullah shows that the potential of national zakat can reach Rp. 19.3 trillion. Fourth, the Firdaus study et al (2012) states that the potential of national zakat in 2011 reached 3.4 percent of the total Gross Domestic Product (GDP), or in other words the potential of zakat in Indonesia is estimated at Rp 217 trillion. This amount includes the potential for zakat receipts from various areas, such as zakat in households, private companies, state-owned enterprises, as well as deposits and savings. Fifth, according to the research of the National Zakat Agency (BAZNAS), the potential of national zakat in 2015 has reached Rp. 286 trillion. This figure is obtained using an extrapolation method that considers the growth of Gross Domestic Product (GDP) in previous years. The potential for zakat in Indonesia as illustrated by various studies has not been supported by the collection of zakat funds in the field. This can be seen from the latest data on the collection of Infaq Shodaqoh Zakat (ZIS) nationally by the official Zakat Management Organization (OPZ) in 2015 which only reached Rp. 3.7 trillion or less than 1.3 percent of its potential (Pusat Kajian Strategis BAZNAS, 2017).

TABLE 1: Amount of National Zakat Receipt Period 2011-2016.

\begin{tabular}{|c|c|c|c|}
\hline Year & $\begin{array}{c}\text { Amount of Zakat } \\
\text { Receipt (Billion } \\
\text { Rupiah) }\end{array}$ & Growth & $\begin{array}{c}\text { Percentage of } \\
\text { Potential Zakat }\end{array}$ \\
\hline 2011 & $1,729.00$ & $15.27 \%$ & $0.80 \%$ \\
\hline 2012 & $2,212.00$ & $27.94 \%$ & $1.02 \%$ \\
\hline 2013 & $2.639,00$ & $19.30 \%$ & $1.22 \%$ \\
\hline 2014 & $3,300.00$ & $25.05 \%$ & $1.52 \%$ \\
\hline 2015 & $3,653.27$ & $10.71 \%$ & $1.68 \%$ \\
\hline 2016 & $5,017.29$ & $37.24 \%$ & $2.31 \%$ \\
\hline
\end{tabular}

Source: Amil Zakat Agency National (2018)

Based on Table 1, it can be seen that the realization of zakat receipts in Indonesia is still very far from the existing zakat potential. The growth of zakat collection from year to year has indeed increased due to people's awareness in paying zakat. However, it is still far from the potential zakat available.

According to Ahmad's research (2011), macroeconomic variables influence the amount of zakat collected in Indonesia. The results showed that inflation and the price of gold had a significant effect on the amount of zakat collected. Fluctuating macroeconomic 
performance will influence people's decisions in allocating funds, including in allocations for social funds such as ZIS.

The inflation rate will cause a decrease in the quality of life of the community, where their biggest expenditure is only used for consumption needs. This shows the soaring prices of goods caused by inflation will make people fall into poverty.

Declining purchasing power does not only have an impact on declining quality of life in fulfilling daily needs, but also affects the religious aspects. Religious practices in Islam related to the economy are the obligation to pay zakat. The high inflation will cause prices of basic commodities to increase. So that community income is more used to meet basic needs. This causes people who were able to pay zakat to be unable to pay zakat. Some even become mustahik (Zen, 2010).

Other macroeconomic variables also influence the amount of zakat collected. Among other things: interest rates, money supply and industrial production index. In Kuran's research (2012) states that interest rates and profit sharing ratios have a reverse relationship with zakat. If interest rates increase, the amount of investment will decrease. This causes the community income to decrease so that the zakat received will decrease.

Tugino (2012)) explains that interest rates affect an individual's decision to spend or save money in the form of savings. High interest rates will increase the costs that must be incurred by the company resulting in a decrease in domestic production activities. When production activities decline, the company zakat that must be issued will also decrease. Thus resulting in a reduction in the amount of zakat collected.

While industrial production has a relationship with zakat. Wahab's research (2012) states that increasing gross domestic product will increase the value of zakat received. GDP is one component of national income that provides information about the economy of a country. GDP can be interpreted as the value of goods and services produced in the country in a given year (Sukirno, 2004). According to the Badan Pusat Statistik (BPS) (2017), the industrial sector is the biggest contributor to GDP. Which is the Indonesian industrial sector contributing $22 \%$ of the total GDP. The industrial production index has a positive relationship with zakat receipts, with increasing industrial production increasing people's purchasing power and ultimately increasing the ability to pay zakat.

Therefore, the authors are interested in conducting this research with the title "Impact of Inflation, Interest Rates and Industrial Production Index (IPI) on the amount of Zakat in the National Baznas Period 2011-2017" by using themethod Vector Error Correction Model (VECM)to know the extent where the influence of macroeconomic variables on the amount of zakat. 
The formulation of the problem proposed is how the influence of inflation, interest rates, and the Industrial Production Index (IPI) on the amount of zakat at the Central BAZNAS.

Based on the problems described above, the general purpose of this study was to analyze the effect of inflation on amount of zakat at the Central BAZNAS, analyze the influence of interest rates on the amount of zakat at the Central BAZNAS and analyze the effect of industrial production index on the amount of zakat at Central BAZNAS.

The hypothesis proposed in this study is: First, inflation has a negative effect on the amount of zakat. Second, Bank Indonesia Interest Rates negatively affect the amount of zakat. Third, the Industrial Production Index has a positive effect on the amount of zakat.

\section{Literature Review}

According to Hafidhuddin (2002), zakat has several meanings, namely blessing (albarakatu), growth and development (al-namaa), holiness (ath-thaharatu). The term zakat is the obligation of Allah SWT on the part of the property with certain conditions to be handed over to those who are entitled to receive it, with certain conditions as well.

Zakat is one of the important pillars among other pillars of Islam, because it has the qath'i arguments in its stipulation. This explains that zakat has a clear legal obligation, and causes disbelief for those who violate it (Al-Bugha, 1996). The Qur'an's obligation on zakat obligations is the word of Allah ta'ala: And establish prayer and pay zakat. (QS Al-Baqarah [2]: 43).

The zakat order is repeated several times in the Qur'an. As the mention of the word zakat is thirty-two places, thirty times with the meaning of zakat and twice with the context and meaning that is not zakat (2012).

Inflation is defined as increasing prices in general and continuously. The increase in the price of just one or two items cannot be called inflation unless the increase is widespread (or results in an increase in prices) on other goods (Bank Indonesia, 2016)). According to Idris (2016) Inflation is an increase in general prices continuously, which will cause the purchasing power of society to increase, so that in the initial stages the goods become scarce, but in the next stage the amount of goods will increase due to the reduced purchasing power of the people.

Inflation can result in a decrease in the real income of the community (Kewal, 2012). This happens because inflation causes the ability of people's purchasing power to decline. When inflation occurs, the increase in wage rates is not as fast as the increase 
in the price of goods in the market. Therefore, there is a decline in the economy of society (Santosa, 2017).

One of the property requirements as an object of zakat is exceeding basic needs (2007). If a person has high income but his expenses are also high so that his property is not excessive then he is not obliged to pay alms. When inflation occurs the prices of basic necessities will increase, so that the allocation of people's income to meet basic needs will increase. This results in a decrease in the value of zakat and can even change the status of muzakki to mustahik.

Interest is the amount of money a lender receives for money lent, and the interest rate is the ratio of interest to the amount of the Ioan (Ambarini, 2017). Interest is one of the variables in the economy that is always closely watched because it has a very broad impact. According to Kasmir (2010), bank interest can be interpreted as reciprocal services provided by banks based on conventional principles to customers who buy or sell their products. Interest for banks can also be interpreted as the price to be paid to customers who have deposits and prices to be paid by customers who obtain loans to banks.

The interest rate is the amount received by the person who lends and is paid by the borrower a percentage of the amount agreed upon by both parties (Subagyo, 2002).

Interest rates can affect company profits, namely in two ways: (1) Because interest is a cost, the higher the interest rate, the lower the company's profit if other things are considered constant; and (2) Interest rates affect the level of economic activity, because it affects company profits. High interest rates on the one hand will increase people's desire to save so that the amount of banking funds will increase (Jatmiko, 2017).

$\mathrm{BI}$ Rate is used as a reference for commercial banks in setting deposit rates and lending rates. The high interest rate will increase the amount of savings, cateris paribus. According to Boediono in Huda et al (2009)if the community estimates that the profit from the investment that will be carried out in a certain period of time is higher than the results to be obtained at the bank, then they will choose to use their funds to invest. Conversely, if interest rates are higher than the value of investment results, the people tend to choose to save rather than invest in the real sector. As a result the output of the real sector production decreases, so the amount of zakat collected from developing assets decreases. Therefore, the BI Rate is inversely proportional to the amount of zakat collected (Fitriah \& Beik, 2015).

According to Kuran's research (2012) states that interest rates and profit sharing ratios have a reverse relationship with zakat. If interest rates increase, the amount of 
investment will decrease. This causes the community income to decrease so that the zakat received will decrease.

The industrial sector has shown an important and strategic role for the national economy, both in increasing added value and in providing welfare to the wider community (BPS, 2009)).

Economic growth is related to an increase in a country's production or an increase in a country's per capita income. Therefore economic growth is closely related to gross domestic product (GDP) or gross regional domestic product (GDP) if it is within the area (Suliswanto, 2010). One of the biggest contributors to GDP in Indonesia is the Industrial Production Index. So that the high GDP depends on the high Industrial Production Index.

Industrial production is the name of an economic indicator that calculates real production output from manufacturing, mining and other manufacturing sectors such as oil and gas and electricity (Djohanputro, 2008).

The Industrial Production Index is an economic indicator that measures the production of real output. IPI is often used as a representation of national income to replace the absence of monthly GDP data (Beik \& Fatmawati, 2014). In Indonesia it is divided into large and medium industries and micro and small industries. The industrial sector is the largest contributor to Gross Domestic Product (GDP) each year. In 2017 it accounts for $22 \%$ of total GDP (BPS 2017). IPI data is a proxy for economic growth, so the increase in IPI will increase national income and will increase the potential of zakat.

According to the Indonesian Central Bureau of Statistics (BPS), the Industrial Production Index (IPI) data was collected from 1,532 industrial companies selected to be monthly and large industrial survey samples using a questionnaire in the form of a shuttle form. The beginning of the use of the monthly Industrial Production Index (IPI), is the fulfillment of the commitment of the government of the Republic of Indonesia who is a member of the International Monetary Fund (IMF) through the Special Data Dissemination Standard (SDDS). IPI is intended as an early monitoring system, so that the monetary or economic crisis does not repeat itself. Starting in 2000, BPS conducted large and medium monthly industry surveys whose samples were integrated with quarterly industry surveys. Since 2000 , data has been processed from 195 companies as a result of the monthly industry survey and used 2000 as the base year (Nugroho, 2009). 


\section{Methodology}

This study uses quantitative methods. According to Sugiyono (2012) the quantitative approach is research data in the form of numbers and analysis using statistics. As for the method used is descriptive method-causality intended to seek an explanation of their causal relationships (cause-effect) between concepts or variables (Ferdinand, 2014). The aim of this research is to find out how the influence of Inflation, BI Rate and IPI on the amount of zakat received at the National BAZNAS 2011-2017.

This study will use data time series with analysis Vector Autoregression (VAR) if the data used is stationary and there is no cointegration, or approach Vector Error Correction Model (VECM)if the data used is known to be stationary and there is cointegration.

Vector Auto Regression (VAR) is a form of econometric model that makes a variable a linear function of the constant and lag of the modifier itself and the value lag of other modifiers contained in a particular system of equations (Firdaus, 2011). VAR was developed by Christopher A. Sims, as an alternative model approach to multiple equation models with the consideration of minimizing a theoretical approach that aims to be able to capture economic phenomena well (Widarjono, 2007).

The data analysis technique used in this study is VECM analysis using tools software Eviews 8. The first step is to test the data with stationarity, stability and cointegration tests. Do not forget to take steps to determine the optimum lag. Furthermore, the model can be tested for effect through the causality tests Engel-Granger and VECM test.

\section{Result}

The first step in this study was to test the stationarity of research data.Stationarity Test (Unit Root Test) uses the approach Augmented Dickey Fuller (ADF). If the value of the probability value (P-Value) is less than 0.05 then the data has been stationary at the real level of five percent (at its level).

TABLE 2: Stationarity Test Results at Level.

\begin{tabular}{l|c|c|c} 
Variable & ADF Statistics & P-Value & Information \\
\hline LN Zakat & 0.380233 & 0.9808 & No Stationary \\
\hline Inflation & -2.409600 & 0.1423 & No Stationary \\
\hline BI Rate & -3.513344 & 0.8956 & Non-Stationary \\
\hline LN IPI & -0.921117 & 0.7768 & Not Stationary \\
\hline Source: Processed Research Data (2018)
\end{tabular}


Based on Table 2, the research data is not stationary at the level of the level. Therefore it must be tested at the stage first difference.

TABLE 3: Stationarity Test at Firs Difference.

\begin{tabular}{l|c|c|c|}
\hline Variable & ADF Statistic & P-Value & Description \\
\hline LN Zakat & -13.82039 & 0.0001 & Stationary \\
\hline Inflation & -6.792323 & 0.0000 & Stationary \\
\hline BI Rate & -6.333057 & 0.0000 & Stationary \\
\hline IPI & -10.55200 & 0.0001 & Stationary \\
\hline \multicolumn{2}{l|}{ Source: Processed Data Research (2018) } \\
\end{tabular}

Based on the results in above it can be concluded that the research data is stationary at level 1st Difference.

The next step is determining the optimum lag. The optimum lag length is determined by looking at the results Likehood Ratio (LR), Final Prediction Error (FPE), Akaike Information Criterion (AIC), Schwarz Information Criterion (SC), and Hannan-Quin Criterion $(\mathrm{HQ})$ which are marked with a star symbol $\left(^{*}\right)$. Lags with the most asterisks will be the chosen lag for estimation at the next stage.

TABLE 4: Optimum Lag Stationarity Test.

\begin{tabular}{l|c|c|c|c|c|}
\hline Lag & LR & FPE & AIC & SC & HQ \\
\hline 0 & NA & 0.01 & 5.83 & 5.96 & 5.88 \\
\hline 1 & 557.28 & 2.66 & -1.48 & $-0.87^{*}$ & -1.24 \\
\hline 2 & $50.34^{*}$ & $1.93^{*}$ & $-1.803^{*}$ & -0.71 & $-1.37^{*}$ \\
\hline 3 & 21.04 & 2.16 & -1.72 & -0.14 & -1.08 \\
\hline 4 & 19.26 & 2.36 & -1.62 & 0.44 & -0.80 \\
\hline 5 & 17.70 & 2.70 & -1.52 & 1.02 & -0.50 \\
\hline 6 & 11.13 & 3.43 & -1.32 & 1.71 & -0.11 \\
\hline 7 & 15.79 & 3.97 & -1.24 & 2.28 & 0.17 \\
\hline
\end{tabular}

Based on Tebel 4, it can be seen that the value contained a sign star ( $\left.{ }^{*}\right)$ is the smallest value found in the criteria, so that the lag at that value is the optimum lag. In this test, the majority of asterisks are in lag 2 . Therefore, in this study lag 2 is the most optimum lag.

Test The stability test aims to ensure the maximum hose length has been stabilized. If the modulus is below one, the model is stable and produces valid predictions (Firdaus, 2011). 
TABLE 5: Stability Test Results.

\begin{tabular}{l|l|}
\hline Root & Modulus \\
\hline$-0.521109-0.496015 i$ & 0.719434 \\
\hline$-0.521109+0.496015 i$ & 0.719434 \\
\hline$-0.591695-0.383914 i$ & 0.705331 \\
\hline$-0.591695+0.383914 i$ & 0.705331 \\
\hline$-0.351191-0.589412 i$ & 0.686106 \\
\hline$-0.351191+0.589412 i$ & 0.686106 \\
\hline$-0.370394-0.534508 i$ & 0.650301 \\
\hline$-0.370394+0.534508 i$ & 0.650301 \\
\hline Source: Processed Research Data (2018)
\end{tabular}

Based on Table, the modulus value for the zakat receipt model ranges from 0.653010,719434 . These results indicate there is no modulus that exceeds one, so it can be concluded that the model is stable at the length of each hose.

Cointegration testing is important to see the long-term balance between the observed variables. An equation is said to have a cointegration relationship if the value of the trace statistic or max eigen satust is greater than the value of itsvalues critical.

TABLE 6: Cointegration Test.

\begin{tabular}{l|c|c|}
$\begin{array}{l}\text { Hypothesized No. } \\
\text { Of CE (s) }\end{array}$ & Trace Statistics & 0.05 Critical Value \\
\hline None * & 60.82758 & 47.85613 \\
\hline At most 1 & 24.47329 & 29.79707 \\
\hline At most 2 & 4.208815 & 15.49471 \\
\hline At most 3 & 0.104357 & 3.841466 \\
\hline Source: Processed Research Data (2018)
\end{tabular}

Based on Table 5, it can be seen that the results of Johansen's cointegration test indicates the existence of cointegration, because of thevalue trace statistic and the eigen max statistic is greater than the critical value $5 \%$. This matter indicates that the movement of variables between the amount of zakat, Inflation, BI rate and IPI has a relationship of stability / balance and similarity long-term movements where in every short-term period, all variables tend to adjust to each other to reach term equilibrium length. 
After the optimum lag test, model stability, and cointegration,causality testing was carried out Engel-Granger. This is done to see the reciprocal influence between the variables of zakat receipts, inflation, interest rates and industrial production index.

TABLE 7: Causality Test Engel-Granger.

\begin{tabular}{l|c|c|}
\hline Hypothesis: & \multicolumn{2}{|c}{ F-Statistic Prob. } \\
\hline $\begin{array}{l}\text { INFLATION is influenced by } \\
\text { LN_ZAKAT }\end{array}$ & 0.40057 & 0.6713 \\
\hline LN_ZAKAT is affected by INFLATION & 2.01045 & 0.1409 \\
\hline BI_RATE is influenced by LN_ZAKAT & 0.48291 & 0.6188 \\
\hline LN_ZAKAT is affected by BI_RATE & 2.71133 & 0.0728 \\
\hline LN_IPI influenced by LN_ZAKAT & 17.3229 & $6 . E-07$ \\
\hline LN_ZAKAT is influenced by LN_IPI & 13.6130 & E-06 \\
\hline Source: Processed Research Data (2018) &
\end{tabular}

Based on Table 7, the results obtained show that at the level of five percent, that is when the probability value is below 0.05 , indicating that each variable does not have a significant effect reciprocity towards the amount of zakat.

VECM model is useful for describing dynamic behavior from the form ofdata timeseries economic and financialand also for forecasting. This model can provide estimates of the effect in the short term as well as long term. This study uses significance with a critical value of $5 \%$, where the t-statistic value is \pm 1.98896 . Variables are stated to have a significant effect if they reject $\mathrm{HO}$ or accept $\mathrm{H} 1$, that is when the t-statistic value> 1.98896 and $<-1.98896$.

Based on Table 8 it can be seen that in the long run, inflation and the $\mathrm{BI}$ rate have a negative significant effect on the amount of zakat. Meanwhile, IPI has a positive and significant effect on the amount of zakat. Whereas in the short term, a significant effect on the amount of zakat is the receipt of zakat 1 in the previous period and 2 previous periods. Thus, in the short-term variable inflation, the $\mathrm{BI}$ rate and IPI do not have a significant effect on the amount of zakat.

Coefficient values of R-squared and Adj. The R-squared in the model is 0.675922 and 0.633651 which means that the amount of zakat variable in the 2011-2017 period can be explained by the inflation variable, BI rate and IPI by $68 \%$ or $63 \%$. While $32 \%$ or $37 \%$ are explained by other variables outside the model.

The results of the VECM test can be presented in the equation model formed from the coefficient value of each variable in the long and long term short. The following 
TABLE 8: VECM Test Results.

\begin{tabular}{|c|c|c|c|}
\hline \multicolumn{4}{|c|}{ Long-Term } \\
\hline Variable & Coefficient & T-Statistic & Description \\
\hline LN_ZAKAT (-1) & 1.000000 & & \\
\hline INFLATION (-1) & -0.405229 & {$[-4.98436]$} & Significant \\
\hline BI_RATE (-1) & -1.066132 & {$[-1.29298]$} & Not Significant \\
\hline LN_IPI (-1) & 26.21863 & [12.9717] & Significant \\
\hline C & 2.010119 & & \\
\hline \multicolumn{4}{|c|}{ Short-Term } \\
\hline Variable & Coefficient & T-Statistic & Description \\
\hline D (LN_ZAKAT (-1) & -0.908771 & {$[-3.08078]$} & Significant \\
\hline D (LN_ZAKAT (-2) & -0.527402 & {$[-3.23955]$} & Significant \\
\hline D (INFLATION (-1) & -0.118695 & {$[-0.86967]$} & No Significant \\
\hline D (INFLATION (-2) & -0.154493 & {$[-1.20840]$} & Not Significant \\
\hline D (BI_RATE (-1) & -0.224488 & {$[-0.43645]$} & Not Significant \\
\hline D (BI_RATE (-2) & -0.362083 & {$[-0.83090]$} & Not Significant \\
\hline D (LN_IPI (-1) & 4.586930 & {$[0.68035]$} & Not significant \\
\hline D (LN_IPI (-2) & 0.584670 & {$[-0.89132]$} & Not significant \\
\hline C & 0.000740 & {$[0.00637]$} & Not significant \\
\hline R-squared & 0.675922 & & \\
\hline Adj. R-squared & 0.633651 & & \\
\hline
\end{tabular}

is the research equation model of the effect of inflation, interest rates and IPI on the amount of zakat in Central BAZNAS in the long term:

D_Zakat $=-0.405229$ Inflation $-1.066132 \mathrm{BI} \_$Rate $+26.21863 \mathrm{IPI}+2.010119$

The equation model of research influences inflation, interest rates and IPI on zakat receipts at BAZNAS Center in the short term:

D_Zakat $=-0.908771$ Zakat $(-1)-0.527402$ Zakat $(-2)-0.118695$ Inflation $(-1)$

- 0.154493Inflation (-2) - 0.224488BI_Rate (-1) -0.362083BI_Rate (-2) +

4,586930 IPI $(-1)+0.584670$ IPI $(-2)+0,000740$

Based on the results of VECM analysis in Table 8, the effect of inflation on the amount of zakat in the short term is negative and not significant. Whereas in the long run inflation has a significant negative effect on the amount of zakat with a coefficient value of -0.405229 which indicates that every increase in the inflation rate of one 
percent will have an impact on the decrease in zakat income by 0.405229 points. Thus, the results of this study accept the hypothesis that there is a negative influence of inflation on the amount of zakat at the Central BAZNAS in the period 2011-2017.

The negative influence of inflation on the amount of zakat is in accordance with the theory of the impact of inflation which explains that rising inflation will increase the price of goods so that the value of the currency will decrease and ultimately will reduce people's purchasing power (Mankiw, 2007). the same from the impact of inflation (Azizah, 2017). In addition, according to Ambarini (2017) inflation can affect the economy, especially the level of prosperity of the community. Inflation will have an impact on income, output, rising interest rates and future economic uncertainty.

The increase in inflation shows an increase in the prices of goods in general, including rice and gold (Thufail \& Batool, 2013). Gold is a determinant of the size of the zakat maal threshold, namely gold and silver zakat or currency zakat, trade zakat and money saving zakat. This is in accordance with the theory that the increase in the price of rice and gold will increase the amount of the Nisab boundary that must be achieved by muzakki.

The results of the study indicate that the $\mathrm{BI}$ rate in the long run has a negative and not significant effect on the amount of zakat. Based on the results of the VECM analysis that has been carried out, the coefficient value obtained is -1.066132 . This indicates that every increase in the $\mathrm{BI}$ rate by one percent will have an impact on the decrease in zakat received by Central BAZNAS amounting to -1.066132 points.

The results of this study indicate that changes in interest rates do not affect the amount of zakat receipts at the Central BAZNAS. So that the results of this study are contrary to the theory which states that interest rates are inversely related to zakat receipts because if interest rates increase, the community does not invest because the interest on loans is too high so that the amount of investment decreases and decreases people's income penuruna also (Kuran, 2012).

The results of this study are in accordance with previous studies conducted by Noviyanti (2016) with the results of the study showing no influence of interest rates on zakat receipts. Likewise the research conducted by Fitriah (2015) which results in the $\mathrm{BI}$ rate not having a significant effect on the amount of zakat in BAZNAS.

Based on the results of VECM analysis in Table 8, the effect of IPI on the amount of zakat in the short term is positive and not significant. Whereas in the long run IPI has a positive and significant effect on zakat receipts with a coefficient of 26.21863 which indicates that every increase in the level of IPI by one point will have an impact on decreasing zakat revenue by 26.21863 points. Thus, the results of this study accept 
the hypothesis of the positive influence of IPI on the amount of zakat at the Central BAZNAS in the period 2011-2017.

The positive influence of IPI on the amount of zakat is in accordance with the existing theory Nurcholis (2005) who said that if GDP increases, the ability to pay will also increase. So that it will increase the amount of zakat. And IPI is often used as a representation of national income to replace the absence of monthly GDP data (Beik \& Fatmawati, 2014). In Indonesia, the industrial sector is the largest contributor to Gross Domestic Product (GDP) each year. In 2017 accounted for 22\% of total GDP (BPS, 2017).

Likewise according to the statement of Noviyanti and Beik (2016) which states that IPI is a proxy for Indonesia's economic growth. Increasing economic growth will increase national income. This will increase the amount of zakat due to an increase in the amount of assets of the zakat object. The amount of zakat that must be paid by muzakki is determined in the form of a percentage so that if the income of muzakki, both individuals and companies increase, the amount of zakat revenue will also increase.

\section{Conclusion}

Based on the results of the research and discussion in the previous chapter, the conclusions of this study can be explained as follows: First, in the short term, the inflation rate has no significant effect on the amount of zakat. Whereas in the long run inflation has a significant negative effect on the amount of zakat. Second, in the short and long term, the BI rate has no significant effect on the amount of zakat. Third, in the short term, IPI has no significant effect on zakat amounts. While in the long term IPI has a significant positive effect on zakat amounts.

Based on the results of this study, it can be obtained the implication that if inflation and interest rates increase, it will result in a decrease in the amount of zakat received at BAZNAS. Meanwhile, the Industrial Production Index (IPI) which has increased will result in an increase in the amount of zakat at BAZNAS.

\section{References}

[1] Ahmad, Z. M. (2011). Pengaruh Indikator Makroekonomi terhadap Besarnya Jumlah Zakat yang Terkumpul di Lembaga Amil Zakat Dompet Dhuafa Republika Tahun 1993-2009. Jakarta: Universitas Indonesia.

[2] Al-Bugha, M. (1996). Al-Fiqh Al-Manhaji Ala Madzhab Al-Imam Asy-Syafi'i. Beirut: Dar Al-Qolam. 
[3] Al-Qardhawi, Y. (1975). Fiqh Az-Zakah. Kairo: Maktabah Wahdah.

[4] Ambarini, L. (2017). Ekonomi Moneter. Bogor: In Media.

[5] Azizah, Y. K. (2017). Analisis Pengaruh Variabel Ekonomi Makro: Suku Bunga, Nisbah Bagi Hasil, Inflasi dan Produksi Industri terhadap Jumlah Zakat yang diterima di Indonesia. Surabaya: Universitas Airlangga.

[6] Az-Zuhaily, W. (2007). Fiqh Al-Is/amy wa Adillatuhu. Damaskus: Dar Al-Fikr.

[7] Bank Indonesia. (2016)). Penjelasan BI Rate. Diambil kembali dari http://www.bi.go. $\mathrm{id} /$ id/moneter/bi-rate/penjelasan/Contents/Default.aspx

[8] Beik, I. S., \& Fatmawati, S. W. (2014). Pengaruh Indeks Harga Saham Syariah dan Variebel Makro Ekonomi terhadap Jakarta Islamic Index. Al-lqtishad: Vol. VI No. 2.

[9] BPS. (2009). Perkembangan Indeks Produksi Industri Besar dan Sedang. Jakarta: Badan Pusat Statistik.

[10] Djohanputro, B. (2008). Prinsip-Prinsip Ekonomi Makro. Jakarta: PPM.

[11] Ferdinand, A. (2014). Metode Penelitian Manajemen. Semarang: Seri Pustaka Kunci.

[12] Firdaus. (2011). Aplikasi Ekonometrika untuk Data Panel dan Time Series. Bogor: IPB Press.

[13] Fitriah, S. N., \& Beik, S. I. (2015). Dampak Makroekonomi terhadap Penghimpunan ZIS di BAZNAS Pusat. Iqtishodia Republika.

[14] Hafidhuddin, D. (2002). Zakat dalam Perekonomian Modern. Jakarta: Gema Insani.

[15] Huda, N. (2009). Ekonomi Makro Islam: pendekatan teoretis. Jakarta : Kencana Prenada Media.

[16] Idris, A. (2016). Ekonomi Publik. Yogyakarta: Deepublish.

[17] Idrus, M. (2009). Metode Peelitian IImu Sosial. Yogyakarta: Erlangga.

[18] Jatmiko, D. P. (2017). Pengantar Manajemen Keuangan. Yogyakarta: Diandra Kreatif.

[19] Kasmir. (2010). Bank dan Lembaga Keuangan Lainnya. Jakarta: RajaGrafindo Persada.

[20] Kewal, S. S. (2012). Pengaruh inflasi, suku bunga, kurs, dan pertumbuhan PDB terhadap indeks harga saham gabungan. Jurnal Economia 8.1, 53-64.

[21] Kuran, T. (2012). Effect of Nisbah and Interest Rate to The Amount of Zakah in Kuala Lumpur. The Journal of Economic Perpectives Vol. 4, 155.

[22] Mankiw, N. G. (2007). Principles of Economics. Thomson: South Western.

[23] Nasution, M. E. (2006). Zakat Dan Wakaf Sebagai Pilar dalam Sistem Perekonomian Nasional. IQTISHODUNA, 1(3). 
[24] Noviyanti, \& Beik, I. S. (2016). Analisis Pengaruh Variabel Makro Terhadap Penerimaan Zakat, Infak dan Sedekah (ZIS) Dompet Dhuafa Periode 2005-2015. lqtishodia Republika.

[25] Nugroho, R. Y. (2009). Analisis Faktor-Faktor Penentu Pembiayaan Perbankan Syariah Di Indonesia: Aplikasi Model Vector Error Correction. Bogor: Institut Pertanian Bogor.

[26] Nurcholis, H. (2005). Pemerintah dan Otonomi daerah. Jakarta: Grasindo.

[27] Pusat Kajian Strategis BAZNAS. (2017). OUTLOOK ZAKAT 2017. 2017: Puskas Baznas.

[28] Samuelson, P. A., \& Nordhaus, W. D. (2004). Ilmu Makro Ekonomi. Jakarta: PT. Media Global Edukasi.

[29] Santosa, A. B. (2017). Analisis Inflasi di Indonesia. Prosiding Seminar Nasional Multidisiplin IImu dan Call Paper Unisba ke-III.

[30] Sarwat, A. (2012). Seri Flqih Kehidupan 4: Zakat. Jakarta: DU Publishing.

[31] Subagyo. (2002). Bank dan Lembaga Keuangan Lainnya. Yogyakarta: Yayasan Keluarga Pahlawan Negara.

[32] Sugiyono. (2012). Metode Penelitian Bisnis. Bandung: Alfabeta.

[33] Sukirno, S. (2004). Makroekonomi: Teori Pengantar. Jakarta: Raja Grafindo Persada.

[34] Suliswanto, M. S. (2010). Pengaruh Produk Domestik Bruto (PDB) dan Indeks Pembangunan Manusia (IPM) Terhadap Angka Kemiskinan di Indonesia. Jurnal Ekonomi Pembangunan, Vol 8 No. 2 Desember 2010.

[35] The Pew Forum on Religion and Public Life. (2017). Muslim Population.

[36] Thufail, S., \& Batool, S. (2013). An analysis of the relationship between inflation and gold prices: evidence from Pakistan. . The Lahore journal of economics, 18(2).

[37] Tugino. (2012). Analisis Faktor-faktor yang Mempengaruhi Penerimaan Pajak Pertambahan Nilai di Indoneia. Medan: Universitas Sumatera Utara.

[38] Wahab, N. (2012). Interrelationship between Gross Domestic Product and Zakat. Journal of Economics Cooperation and Development Vol 33, 95-112.

[39] Widarjono, A. (2007). Ekonometrika: Teori dan Aplikasi untuk Ekonomi dan Bisnis. Yogyakarta: Ekonisia.

[40] Zen, M. (2010, January 27). Potensi Zakat dan Pemberdayaan Wirausaha. Diambil kembali dari http://imz.or.id/new/article/117/potensi-zakat-dalam-pemberdayaanwirausaha 